\title{
Development of ISSR PCR markers for diversity study in dogwood (Cornus spp.)
}

\author{
Ainong Shi ${ }^{1,3}$, Stella Kantartzi ${ }^{2}$, Margaret Mmbaga $^{3}$, and Pengyin Chen ${ }^{4}$ \\ ${ }^{1}$ Syngenta Seeds, 2369 - 330th St. Slater, IA 50224, USA; ${ }^{3}$ Otis L. Floyd Nursery Research \\ Center, Tennessee State University, McMinnville, TN 37110, USA; ${ }^{2}$ Department of Plant, Soil \\ and Agricultural Systems, Southern Illinois University Carbondale, Carbondale, IL 62901, \\ USA; ${ }^{4}$ Department of Crop, Soil, and Environmental Sciences, University of Arkansas, \\ Fayetteville, AR 72701, USA. \\ * Corresponding author. Email: ainong.shi@syngenta.com or ainong_shi@hotmail.com \\ ABSTRACT
}

\begin{abstract}
Several commercial cultivars and new selections of dogwood (Cornus spp.) were analyzed for genetic diversity using 19 Inter-Simple Sequence Repeats (ISSR) primer pairs. Out of 22 genotypes analyzed, 14 were of $C$. florida, two of $C$. mas, one of $C$. nutalli, two of $C$. kousa, and also three were hybrids between $C$. kousa and $C$. florida. The $C$. florida genotypes included five commercial cultivars, most of which were susceptible to powdery mildew, and nine new selections, most of which were resistant to powdery mildew. Results from the ISSR primers revealed molecular-marker profiles that were genotype specific thus providing a good tool for DNA fingerprinting Cornus species.
\end{abstract}

Keywords: Dogwood, Cornus spp., ISSR, genetic diversity

Abbreviations: ISSR, Inter-Simple Sequence Repeat \section{INTRODUCTION}

Flowering dogwood (Cornus florida) is one of America's most popular ornamental trees. Flowering dogwoods are extremely valuable for wildlife because the seed, fruit, flowers, twigs, bark, and leaves are utilized as food by various animals. Flowering dogwood is seriously threatened by a powerful fungus, powdery mildew and disease management relies almost solely on routine fungicide applications. Host resistance is recognized as the best method for disease management, but the absence of high-level resistance within C. florida is a problem (Windham 1996; Hagan et al. 1995; 1998). Among C. florida, only two commercial cultivars "Cherokee Brave" and "Fragrant Cloud" have displayed powdery mildew resistance (Mmbaga and Sauve 2004), and conventional breeding for disease resistance may require decades because of the long generation time. New sources of powdery mildew resistance from genetically diverse plants generated from natural outcrossing have been identified and show clearly that host resistance is available in C. florida (Windham et al 2000; Mmbaga and Sheng, 2001). Such selections can be further developed into a new generation of commercial cultivars that can replace the susceptible genotypes. It was reported the $C$. florida relatives, $C$. mas, C. nutalli, C. kousa were high resistant to powdery mildew (Mmbaga and Sauve 2004). Although it is desirable to eliminate susceptible cultivars from the production system, it is also important to maintain plant diversity (Cline et al. 1998). Recent advancements in molecular biology have shown that DNA molecular marker systems can be used to study genetic diversity and better understand the genetic background of new dogwood selections before their introduction into the production system.

PCR-based techniques have been used extensively in genetic analysis and identification of molecular markers in plants. Simple sequence repeats (SSRs) are considered as a marker of choice for genetic mapping and genetic estimations of germplasm resources (McCough et al. 1997; Mitchell et al. 1997; Estoup and Angers 1998). ISSR (Inter-Simple Sequence Repeat) analysis, developed by Zietkiewicz et al. (1994), which uses the SSR motif per se as the single primer in PCR amplifications, does not require the knowledge of flanking sequences and has wide applications for all organisms, regardless of the availability of information about their genome sequence. ISSR has been proven to be a simple and reliable marker system for many organisms, especially plants, with highly reproducible results and abundant polymorphisms. ISSR analysis has been successfully applied in gene tagging (Ammiraju et al. 2001; Ratnaparkhe et al.1998; Sica et al. 2005; Wolfe, 1998), variety fingerprinting or genetic diversity 
Agric. Biol. J. N. Am., 2010, 1(3): 189-194

analysis (Bornet et al. 2002; 2004; Archak et al. 2003), and the evaluation of microsatellite motif frequencies in the rice genome (Blair et al. 1999). For successful ISSR analysis, pairs of SSRs (inversely oriented) must occur within a short distance on the same chromosome, which is amplifiable by a PCR reaction to give a band that is resolvable on agarose or polyacrylamide gels. The primers used in ISSR analysis may be developed from any SSR motifs (di-, tri-, tetra-nucleotides). The potential applications of ISSR analysis for diverse aims depend on the variety and frequencies of microsatellites within the specific genomes.

The objectives of this research were to develop genetic marker systems for use in genetic programs of dogwood (Cornus spp.) and also to analyze the genetic diversity in dogwood accessions.

\section{MATERIALS AND METHODS}

Plant material: A total of 22 dogwood accessions (14 of C. florida, two C. kousa, one C. nutalli, two $C$. mas and three hybrids between $C$. kousa and $C$. florida) including five commercial cultivars and nine new selections of $C$. florida were used in this study. All 22 accessions were previously characterized for powdery mildew resistance/susceptibility; six of the commercial cultivars had powdery mildew resistance, 3 were moderately resistant and four were susceptible (Table 1). In addition, the nine new $C$. florida selections were resistant in total (Table 1).

Molecular and data analyses: Approximately 200 mg of young plant tissue from terminal buds were used for genomic DNA extraction. DNA was extracted and purified from all samples using Qiagen DNeasy ${ }^{\mathrm{TM}}$ Plant Minikit following the protocol of the manufacturer (Qiagen Inc, Valencia, CA). A total of 19 ISSR primers (CATA $)_{4},(\mathrm{CT})_{10},(\mathrm{CT})_{8},(\mathrm{CA})_{10},(\mathrm{AT})_{5}$, $(\mathrm{GA})_{10},(\mathrm{TG})_{10},(\mathrm{GGA})_{4},(\mathrm{GTGTGG})_{3},(\mathrm{CA})_{5},(\mathrm{TA})_{4}$, $(\mathrm{TCCCAT})_{2}, \quad(\mathrm{GTG})_{5}, \quad(\mathrm{GAC})_{5}, \quad(\mathrm{GACA})_{5}, \quad(\mathrm{CAC})_{5}$, $(\text { TGTC })_{5},(\text { GACA })_{5},(\text { GATA })_{4}$ were selected from DNA sequence of $C$. florida published on the GenBank and from common ISSR primers reported to have amplified other plants (Cabe and Liles 2002; Martin and Diez 1996; Reddy et al. 2001). The 19 ISSR primers were used to amplify the inter-repeat regions in the genomic DNA of 22 dogwood accessions using standard PCR procedures with minor modifications. Each $50 \mu \mathrm{l} \mathrm{PCR}$ reaction mixture consisted of $38 \mu \mathrm{l}$ sterile $\mathrm{ddH}_{2} \mathrm{O}, 5 \mu \mathrm{l}$ of $10 \mathrm{X}$ PCR buffer, $3 \mu \mathrm{l}$ of $\mathrm{MgCl}_{2}$ (25 mM), $1.5 \mu$ of dNTP (10 mM total, $2.5 \mathrm{mM}$ each), $1 \mu \mathrm{l}$ of primer $(50 \mu \mathrm{M}), 0.2 \mu \mathrm{l}$ of Taq polymerase (Promega) $(5 \mu / \mu \mathrm{l})$, and $1.3 \mu \mathrm{l}$ of template DNA (20 $\mathrm{ng} / \mu \mathrm{l})$. A Techne Progene ${ }^{\mathrm{TM}}$ (Princeton, NJ, USA) thermal cycler was used and an initial denaturation step was at $94^{\circ} \mathrm{C}$ for 5 min followed by 42 cycles with $1 \mathrm{~min}$ at $92^{\circ} \mathrm{C}$ (denaturation), $1 \mathrm{~min}$ at $30^{\circ} \mathrm{C}$ to $60^{\circ} \mathrm{C}$ (annealing), and $2 \mathrm{~min}$ at $72^{\circ} \mathrm{C}$ (extension). The annealing temperature was $5^{\circ} \mathrm{C}$ less than the primer $\mathrm{Tm}(\mathrm{Tm}-5)$. An extension cycle at $72{ }^{\circ} \mathrm{C}$ for $5 \mathrm{~min}$ was used to terminate the reaction before a final soak at $4^{\circ} \mathrm{C}$. The PCR products were visualized in $2.0 \%$ gels with $50 \%$ regular agarose and $50 \%$ metaphor agarose in $1 \mathrm{X}$ TBE, stained with ethidium bromide, or in $5 \%$ polyacrylamide gels with silver staining.

Allele size ranges were estimated visually by comparison with a standard 100-bp DNA ladder. SSR alleles were scored as 0 for absent/recessive state, 1 for present/ dominant state, and 2 for occasional no amplification/ missing data state. Genetic distance and phylogenetic analyses were performed using Neighbor Joining (NJ) algorithms with the minimum evolution objective function (Saitou and Nei 1987) of the software package NTSYS 2.1. The NTSYS 2.1 genetic distance matrix has been also used for principal component analyses (PCA) to better visualize the genetic distance data.

\section{RESULTS AND DISCUSSION}

Nineteen ISSR primers were amplified using genomic DNAs of 22 dogwood accessions. ISSR primers $(\mathrm{GTGTGG})_{3},(\mathrm{CA})_{5},(\mathrm{TA})_{3},(\mathrm{GTG})_{5},(\mathrm{GAC})_{5},(\mathrm{GACA})_{5}$, $(\mathrm{TGTC})_{5}$, and $(\mathrm{GATA})_{4}$ produced polymorphic markers within the 22 dogwood accessions. An example of the DNA polymorphism pattern from primer $(\mathrm{GAC})_{5}$ fragments is presented in Figure 1. Bands from some primers appeared specific for different species and may have potential use as molecular markers for differentiating Cornus spp. The C. kousa genotypes and all hybrids with C. kousa showed polymorphism with primers (GTGTGG) ${ }_{3}$ at $550 \mathrm{bp},(\mathrm{GAC})_{5}$ at $690 \mathrm{bp}$, and (GATA) $)_{4}$ at $610 \mathrm{bp}$, and these polymorphism were not observed in other species. Two markers, $(\mathrm{CA})_{5}(\mathrm{TA})_{4^{-}}-910$ and $(\mathrm{GAC})_{5^{-}}$ 870 , were observed in all genotypes of $C$. florida and all hybrids with $C$. florida. Two molecular markers (GTG) $)_{5}-610$ and (GTG) $)_{5}-1000$ observed only on C. mas "Redstone" and "Golden Glory", while three markers, (GTGTGG) $)_{3}-340, \quad(G T G)_{5}-850, \quad$ and (GATA) ${ }_{4}-660$ observed only in $C$. nutalli "Boyd". However, the sample size for C. mas and C. nutalli were too small to draw conclusions on the overall specificity of these markers for these two Cornus spp.. The markers (GACA) $)_{5}-290$ and (GATA) $)_{4}-580$ were only present in "Cherokee Princess" and (GATA) $4^{-}$ 540 was observed in only "Ruth Ellen".

Table 1. Dogwood accessions and their reaction to powdery mildew 


\begin{tabular}{|c|c|c|c|}
\hline \# & $\begin{array}{l}\text { Cornus } \\
\text { species }\end{array}$ & $\begin{array}{l}\text { Cultivar names } \\
\text { and selections }\end{array}$ & $\begin{array}{l}\text { Powdery } \\
\text { mildew } \\
\text { reaction }\end{array}$ \\
\hline 1 & C. nutalli & "Boyd" & $\mathrm{S}$ \\
\hline 2 & C. mas & "Redstone" & $\mathrm{R}$ \\
\hline 3 & C. mas & "Golden Glory" & $\mathrm{R}$ \\
\hline 4 & C. kousa & "Milky Way" & $\mathrm{R}$ \\
\hline 5 & C. kousa & "China Girl" & $\mathrm{R}$ \\
\hline 6 & $\begin{array}{l}\text { C. florida } \times C \text {. } \\
\text { kousa }\end{array}$ & "Ruth Ellen & MR \\
\hline 7 & $\begin{array}{l}\text { C. florida } \times C \text {. } \\
\text { kousa }\end{array}$ & "Celastial" & $\mathrm{R}$ \\
\hline 8 & $\begin{array}{l}\text { C. florida } \times C \text {. } \\
\text { kousa }\end{array}$ & "Stellar Pink" & $\mathrm{R}$ \\
\hline 9 & C. florida & "Fragrant Cloud" & $\mathrm{S}$ \\
\hline 10 & C. florida & "Cherokee Brave" & MR \\
\hline 11 & C. florida & $\begin{array}{l}\text { "Cherokee } \\
\text { Princess" }\end{array}$ & $\mathrm{S}$ \\
\hline 12 & C. florida & "Pygmy" & $\mathrm{S}$ \\
\hline 13 & C. florida & "Sterling Silver" & MR \\
\hline $\begin{array}{l}14- \\
17\end{array}$ & $\begin{array}{l}\text { C. florida } \\
\text { selections }\end{array}$ & $\begin{array}{l}\text { MI-5; MI-7; MI-8; } \\
\text { MI-9 }\end{array}$ & $\mathrm{R}$ \\
\hline 18 & $\begin{array}{l}\text { C. florida } \\
\text { selections }\end{array}$ & TR-3 & $\mathrm{R}$ \\
\hline $\begin{array}{l}19- \\
20\end{array}$ & $\begin{array}{l}\text { C. florida } \\
\text { selections }\end{array}$ & WR-19; WR-20 & $\mathrm{R}$ \\
\hline $\begin{array}{l}21- \\
22\end{array}$ & $\begin{array}{l}\text { C. florida } \\
\text { selections } \\
\text { C. florida } \\
\text { selections }\end{array}$ & $\begin{array}{l}\text { RN-14; RN-22 } \\
\text { TR3 }\end{array}$ & $\begin{array}{l}\mathrm{R} \\
\mathrm{R}\end{array}$ \\
\hline
\end{tabular}

${ }^{\mathrm{z}}$ The dogwood selections were obtained from plants generated from natural open pollination at different locations in Tennessee ${ }^{y}$ Powdery mildew reactions reported by Mmbaga et al. (2001) and Mmbaga and Sauve (2004, 2007): Susceptible (S), Moderately Resistant (MR), and Resistant (R)

These results indicate that DNA analysis of the ISSR may be a good tool for DNA fingerprinting of dogwood cultivars. The ISSR technique may also be used to identify interspecific hybrids derived from open pollinations.

The NJ tree (Fig. 2) demonstrated a genetic distance between the different dogwood species studied. According to results, all C. kousa and C. florida accessions clustered together respectively. Species C. mas are showed between $C$. nutalli and C. kousa. Furthermore, the PCA based on genetic distance matrix was used to better visualize the genetic structure of the studied dogwood species. PCA biplot (Fig. 3) placed all C. florida in one big cluster, separating it from the other species (C. nutalli, $C$. mas, C. kousa) and hybrids (C. kousa x C. florida). PCA biplot placed hybrids between the two parental species, two of them closer to C. kousa and one closer to $C$. florida. The results of the PCA once more demonstrated that the microsatellite primers (ISSR) that used are highly informative for distinguishing the studied species with accuracy.

Previous reports on genetic analysis of $C$. florida has raised questions on the validity of some cultivars (Windham and Trigiano 1998). A previous studies based on DNA amplification fingerprinting (DAF), a RAPD technique (Caetano-Anolles et al. 1991) and AFLP (Mmbaga and Sauve, 2004, 2007) have suggested that genetic diversity in the tested $C$. florida varieties and selections is low. Genomic analysis has been recommended as a more precise tool for genotype comparisons of flowering dogwood before new cultivars are released; this would avoid introducing cultivars that are genetically identical (Windham and Trigiano, 1998). Results from this study have shown that the new powdery mildewresistant selections of $C$. florida are genetically diverse and represent a genetic resource for the powdery mildew resistance breeding (Mmbaga and Sheng, 2001; Mmbaga and Sauve, 2004, 2007; Reed 1999). Results from the AFLP analysis (Mmbaga and Sauve, 2007) also showed that the use of new selections of $C$. florida to replace the susceptible commercial cultivars, would maintain or enhance genetic diversity in the production system. 
Agric. Biol. J. N. Am., 2010, 1(3): 189-194

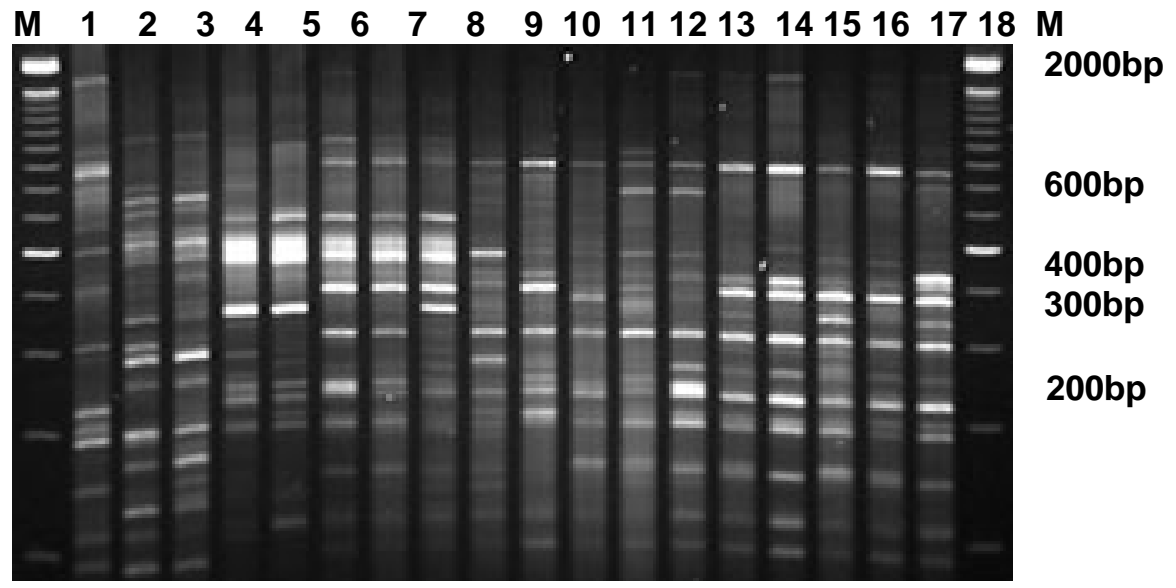

Fig. 1. Amplification pattern of DNA detecting primer (GAC) $)_{5}$ fragments in 18 dogwood accessions. Lane $M$ is a 100bp molecular-weight marker.

Numbers 1-18 represent the panel of dogwood accessions described in Table 1

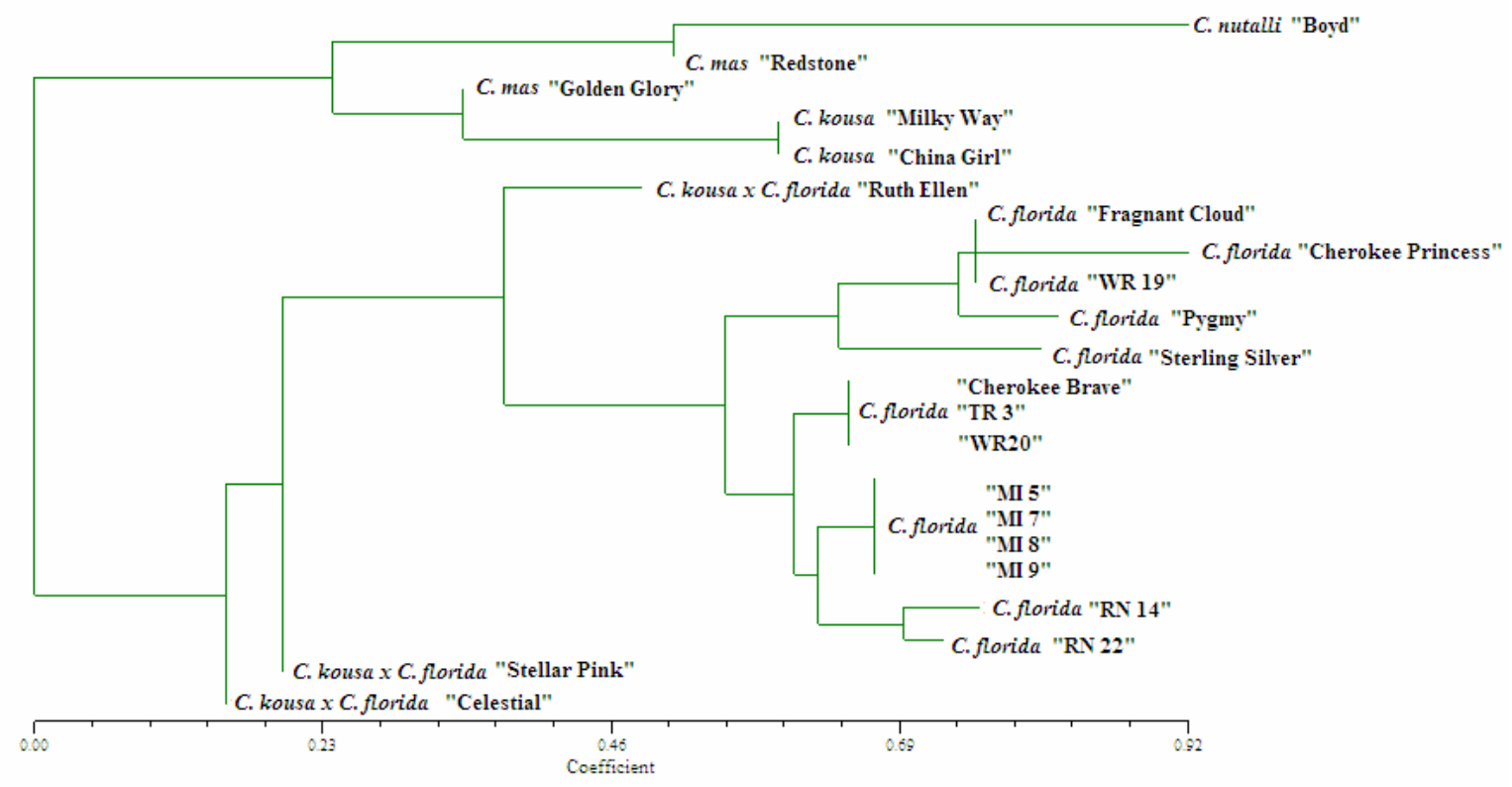

Fig. 2. The phylogenetic rooted $\mathrm{NJ}$ tree 
Agric. Biol. J. N. Am., 2010, 1(3): 189-194

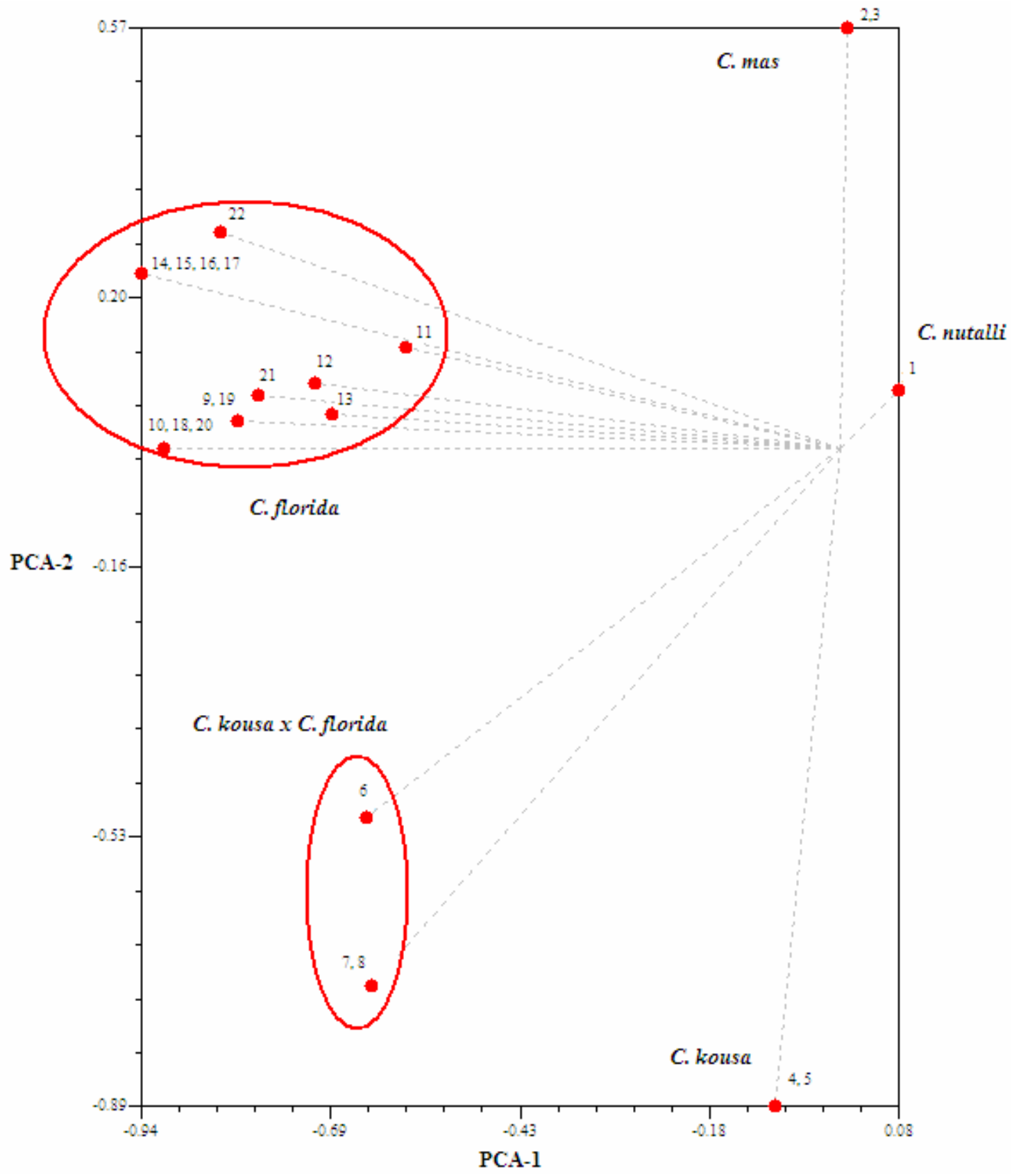

Fig. 3. Biplot derived from the PCAs of genetic distance matrix. Numbers 1-22 represent the panel of dogwood accessions described in Table 1

\section{REFERENCES}

Ammiraju, J. S. S., Dholakia, B. B., Santra, D. K., Singh, H., Lagu, M. D., Tamhankar, S. A., Dhaliwal, H. S., Rao, V. S., Gupta, V. S. and Ranjekar, P. K. (2001). Identification of inter simple sequence repeat (ISSR) markers associated with seed size in wheat. Theor. Appl. Genet. 102: 726-732.

Archak, S., Gaikwad, A. B., Gautam, D., Rao, E. V. V. B., Swamy, K. R. M. and Karihaloo, J. L. (2003).
Comparative assessment of DNA fingerprinting techniques (RAPD, ISSR, and AFLP) for genetic analysis of cashew (Anacardium occidentale L.) accessions of India. Genome 46: 362-369

Blair, M. W., Panaud, O. and McCouch, S. R. (1999). Intersimple sequence repeat (ISSR) amplification for analysis of microsatellite motif frequency and fingerprinting in rice (Oryza sativa L.). Theor. Appl. Genet. 98: 780-792. 
Bornet, B., Muller, C., Paulus, F. and Branchard, M. L. (2002). Highly informative nature of inter simple sequence repeat (ISSR) sequences amplified using triand tetra-nucleotide primers from DNA of cauliflower (Brassica oleracea var. botrytis L.). Genome 45: 890896

Bornet, B. and Branchard, M. (2004). Use of ISSR fingerprints to detect microsatellites and genetic diversity in several related Brassica taxa and Arabidopsis thaliana. Hereditas 140(3): 245-248.

Cabe, P.R. and Liles, J. S. (2002). Dinucleotide microsatellite loci isolated from flowering dogwood (Cornus florida L.). Journal Mol. Ecol. Notes 2(2): 150152

Caetano-Anolles, G., Bassam, B. J. and Gresshoff, P. M. (1991). High resolution DNA amplification fingerprinting using very short arbitrary oligonucleotide primers. Bio/Technology 9:553-557

Cline, M. N., Charstagner, G. A., Aragaki, M., Baker, R., Daughtrey, M. L., Lawson, R.H, McDonald, J. M., Tammen, J. F. and Worf, G. L. (1998). Current and future research directions of ornamental pathology. Plant Dis. 72: 926-935.

Estoup, A. and Angers, B. (1998). Microsatellites and minisatellites for molecular ecology: theoretical and empirical considerations. In: Carvalho GR, editor. Advances in Molecular Ecology. Nato Sciences Series. Amsterdam: IOS Press. p. 55-86.

Hagan, A. K., William, J. D., Eakes, J. 1998. Susceptibility of cultivars of several dogwood taxa to powdery mildew and spot anthracnose. Journal of Environmental Horticulture 16 (3): 147-151.

Hagan, A.K., and J. Mullen, (1995). Controlling powdery mildew on ornamentals. University of Alabama Circular ANR-407.

Martin, F., Costa, G., Delaruelle, C. and Diez, J. (1996). Genomic fingerprinting of ectomycorrhizal fungi by microsattellite-primed PCR. In: Mycorrhiza manual. (A. Varma, B. Hock, Eds) Springer Lab. Manual.

McCough, S. R., Chen, X., Panaud, O., Temnykh, S., Xu, Y., Cho, Y. G., Huang, N., Ishii, T. and Blair, M. (1997). Microsatellite marker development, mapping and applications in rice genetics and breeding. Plant Mol Biol. 35: 89-99.

Mitchell, S. E., Kresovich, S. and Jester, C. A. (1997). Application of multiplex PCR and fluorescence-based, semi-automated allele sizing technology for genotyping plant genetic resources. Crop Sci. 37: 617-624.

Mmbaga, M. T. and Sheng, H. (2001). Host resistance to Microspharea pulchra in dogwood. Proceed. Southern Nursery Assn. Res. Conf. 46: 292-295.
Mmbaga, M. T. and Sauve, R. J. (2004). Multiple disease resistance in dogwoods (Cornus spp.) to foliar pathogens. Journal of Arboriculture 30: 101-106.

Mmbaga, M. T., and Sauve, R. J. (2007). Analysis of powdery mildew-resistant dogwood accessions using AFLP. Hortscience 42 (1): 28-30.

Ratnaparkhe, M. B., Tekeoglu, M. and Muehlbauer, F. J. (1998). Inter simple sequence repeat (ISSR) polymorphisms are useful for finding markers associated with disease resistance gene clusters. Theor. Appl. Genet. 97: 515-519.

Reed, S. M. (1999). Development of a labor-efficient hand pollination procedure for flowering dogwood. J. Environ. Hort. 17: 92-94.

Reddy, O.U.K., Pepper, A. E., Abdurakhmonov, I., Saha, S., Jenkins, J. N., Brlek, Y. and El-Zik, K. M. (2001). New dinucleotide and trinuceotide microsatellite markers resources for cotton genome research. The Journal of Cotton Science 5: 103-113.

Saitou, M. and Nei, N. (1987). The neighbor joining method: a new method for reconstructingphylogenetic trees. Mol. Biol. Evol. 4: 406-425

Sica, M., Gamba, G., Montieri, S., Gaudio, L., and Aceto, S. (2005). ISSR markers show differentiation among Italian populations of Asparagus acutifolius L. BMC Genetics 6:17

Windham, M. T., Trigiano, R. N. and Wittie, W. T. (2000). New dogwood cultivars resistant to powdery mildew. Proceed. Of S. Nursery Assn. Res. Conf 45: 204-206

Windham, M. T. (1996). Resistance to powdery mildew in flowering dogwood. Proceed. of S. Nursery Assn. Res. Conf. 41: 195-199.

Windham, M.T. and Trigiano, R. N. (1998). Are 'Barton' and 'Cloud Nine' the same cultivar of flowering dogwood? J. Environ. Hort. 16: 163-166.

Wolfe, A. D., Xiang, Q. Y., and Kephart, S. R. (1998). Assessing hybridization in natural populations of Penstemon (Scrophulariaceae) using hypervariable inter simple sequence repeat markers. Mol Ecol 7:1107-1125.

Wolfe, A. D., Xiang, Q. Y., and Kephart, S. R. (1998). Diploid hybrid speciation in Penstemon (Scrophulariaceae). Proc. Natl. Acad. Sci. USA 95:5112-5115.

Zietkiewicz, E., Rafalski, A. and Labuda, D. (1994). Genome fingerprinting by simple sequence repeat (SSR)-anchored polymerase chain reaction amplification. Genomics 20: 176-183 